\title{
Kanker Payudara Pasca Kemoterapi dengan Neutropenia: Laporan Kasus
}

\author{
Anita Rahmawati, ${ }^{1}$ Pearla Lasut $^{2}$ \\ ${ }^{1}$ PPDS Bagian Penyakit Dalam Fakultas Kedokteran Universitas Sam Ratulangi Manado \\ ${ }^{2}$ Bagian Penyakit Dalam Fakultas Kedokteran Universitas Sam Ratulangi Manado \\ Email: febeanita1986@gmail.com
}

\begin{abstract}
Febrile neutropenia is found in $10-50 \%$ of post chemotherapy patients with solid tumor and in more than $80 \%$ of patients with hematological malignancy. We reported a case of febrile neutropenia, local chemoport infection, and right breast cancer on chemoterapy in a 47year-old female. Diagnosis was based on symptoms, clinical features, and laboratory examination with absolute neutrophil count (ANC) $460 \mathrm{cells} / \mathrm{mm}^{3}$. This patient was treated with IVFD $\mathrm{NaCl}$ 0.9\% 20 drops/minute, ceftazidime 2 g every 8 hour intravenous, and filgastrim $300 \mathrm{mcg}$ every 24 hours subcutan. The prognosis of this patient was as follows: ad vitam was dubia ad malam, ad functionam was dubia ad bonam, and ad sanationam was dubia.
\end{abstract}

Keywords: febrile neutropenia, post chemotherapy

\begin{abstract}
Abstrak: Febrile neutropenia terjadi pada 10-50\% pasien pasca kemoterapi dengan tumor padat dan lebih dari $80 \%$ pasien pasca kemoterapi dengan keganasan hematologik. Kami melaporkan sebuah kasus seorang perempuan berusia 47 tahun dengan febrile neutropenia, infeksi lokal chemoport, dan kanker payudara on kemoterapi. Diagnosis ditegakkan berdasarkan anamnesis, gejala dan tanda klinis, serta pemeriksaan laboratorium absolute neutrophil count (ANC) 460 $\mathrm{sel} / \mathrm{mm}^{3}$. Pasien diberikan terapi infus $\mathrm{NaCl} 0,9 \% 20$ tetes/menit, ceftazidime injeksi 2 gr setiap 8 jam, dan filgastrim injeksi $300 \mathrm{mcg}$ setiap 24 jam subkutan. Prognosis pasien ini secara ad vitam ialah dubia ad malam, ad functionam ialah dubia ad bonam, dan ad sanationam ialah dubia.
\end{abstract}

Kata kunci: febrile neutropenia, pasca kemoterapi

\section{PENDAHULUAN}

Febrile neutropenia merupakan keadaan dimana terjadi netropenia yang ditegakkan bila nilai absolute neutrophil count (ANC) $<500 \mathrm{sel} / \mathrm{mm}^{3}$, atau $<1.000 \mathrm{sel} / \mathrm{mm}^{3}$ dengan kecenderungan menurun menjadi $<500 / \mathrm{mm}^{3}$ dalam 2 hari. Untuk definisi demam pada kondisi febrile neutropenia terdapat beberapa nilai acuan. European Organization for Research and Treatment of Cancer (EORTC) menggunakan nilai cut off suhu tubuh $\geq 38,5^{\circ} \mathrm{C}$ satu kali pengukuran atau suhu tubuh $\geq 38^{\circ} \mathrm{C}$ dua kali pengukuran dalam jangka waktu dua jam. Indonesia sendiri menggunakan nilai cut off suhu aksila $\geq 38^{\circ} \mathrm{C}$ dua kali pengukuran dalam jangka waktu satu jam atau lebih (kanker padat) dan suhu aksila $\geq 37,5^{\circ} \mathrm{C}$ (keganasan hematologi) atau suhu aksila $\geq 38,3^{\circ} \mathrm{C}$ dalam satu kali pengukuran dan tidak didapatkan tanda-tanda infeksi. ${ }^{1}$

Studi yang dilakukan di Amerika Serikat oleh Kuderer tahun 2006, melaporkan angka mortalitas sebesar 9,5\% pada kelompok pasien febrile neutropenia yang menjalani rawat inap. Studi retrospektif yang dilakukan Ranuhardy di Ruang rawat Isolasi Imunitas Menurun (RIIM) RS Kanker Dharmais pada tahun 2009, melaporkan angka kejadian febrile neutropenia sebanyak 22 dari 40 episode perawatan $(55 \%)$ yaitu 16 orang dari total 28 pasien yang 
keseluruhannya dirawat akibat keganasan hematologik. Angka mortalitas dilaporkan sebesar $27,3 \%$ pada pasien yang mengalami febrile neutropenia. ${ }^{1}$ Demam akibat infeksi pada pasien kanker umumnya toksik, menggigil, takikardi, kadang-kadang hipotensi sampai dengan syok. Demam kanker biasanya bersifat intermiten sedangkan demam karena infeksi biasanya tidak. ${ }^{2}$

Pembagian faktor risiko dari Bakornas Hompedin (Badan Koordinasi Nasional Hematologi Onkologi Medik Penyakit Dalam Indonesia) tahun 2006 didasarkan pada jenis tumor (tumor padat atau hematologik), tipe kemoterapi (kemoterapi konvensional/intensif/agresif), adanya komorbiditas dan lamanya kondisi neutropenia. ${ }^{1}$ Febrile neutropenia terjadi $10-15 \%$ pasien setelah kemoterapi dengan tumor padat dan lebih dari $80 \%$ setelah kemoterapi dengan keganasan hematologik. Pasien berusia di atas 65 tahun memiliki risiko dua kali lipat mengalami febrile neutropenia. ${ }^{3}$ Jenis kelamin perempuan paling sering berhubungan dengan terjadinya febrile neutropenia. ${ }^{4}$

Pemeriksaan darah sebagai baku emas adanya infeksi bakteri ialah kultur darah positif, ditunjang oleh ditemukannya toksik granulasi pada gambaran darah tepi, dan berbagai sitokin sebagai petanda infeksi. ${ }^{5}$

Pada pasien febrile neutropenia sangat diperlukan pengobatan empirik sebelum diperoleh hasil kultur mikrobiologi. Antibiotik yang bersifat bakterisidal dan broad spectrum dipilih pada keadaan ini. Pemberian anti jamur untuk pasien risiko ringan atau sedang dapat dimulai pada hari ke 6-8 sedangkan untuk risiko tinggi pada 72-96 jam. ${ }^{1}$ Sebuah obat sintesis yang merangsang produksi sumsum tulang Recombinant Human Granulocyte Colony Stimulating Factor (G-CSF) telah digunakan untuk mengobati neutropenia kronis yang parah. $^{6}$ Berikut ini dilaporkan seorang pasien dengan kanker payudara kanan pasca kemoterapi disertai komplikasi febrile neutropenia.

\section{LAPORAN KASUS}

Seorang pasien Ny. TS, usia 47 tahun, suku Jawa, menikah, pekerjaan PNS, bertempat tinggal di Perum Paniki, Kota Manado, masuk RSUP Prof. Dr. R. D. Kandou tanggal 27 November 2017 melalui Instalasi Rawat Darurat Medik Penyakit Dalam dan selanjutnya dirawat di IRINA C1 dengan keluhan utama demam. Demam dialami pasien 3 hari sebelum masuk rumah sakit (MRS), demam naik turun, demam turun bila minum obat penurun panas. Pasien juga mengeluhkan nyeri menelan sejak 3 hari sebelum masuk rumah sakit. Mual muntah juga dirasakan pasien, dalam sehari pasien muntah 2 kali, muntah berisi makanan, tidak terdapat darah. Pasien mengeluhkan nyeri tulang dan nyeri pada daerah chemoport. Tidak terdapat batuk, kelainan buang air kecil (BAK) maupun buang air besar (BAB).

Pasien dilakukan eksisi pada payudara kiri tahun 2004, kemudian pada tahun 2010 dilakukan eksisi pada payudara kanan. Pada tahun 2017 dilakukan mastekstomi radikal pada payudara kanan. Pada tanggal 7 November 2017 dilakukan pemasangan chemoport. Pasien telah mendapatkan 4 siklus kemoterapi dengan paclitaxel dan doxorubicin. Kemoterapi terakhir dilakukan pada tanggal 13 November 2017. Riwayat sakit gula, kolesterol, tekanan darah tinggi, dan asam urat tidak ada. Riwayat gangguan paru dan jantung sebelumnya disangkal. Riwayat minum alkohol dan merokok disangkal.

Pada pemeriksaan fisik didapatkan keadaan umum tampak sakit sedang, kesadaran kompos mentis, tinggi badan $160 \mathrm{~cm}$, berat badan $55 \mathrm{~kg}$, indeks massa tubuh (IMT) $21,4 \mathrm{~kg} / \mathrm{m}^{2}$. Status penampilan pasien yang diukur dengan menggunakan Karnofsky performance scale mendapatkan skala $80 \%$, dengan pertimbangan pasien masih dapat melakukan aktivitas walaupun dengan upaya. Dengan menggunakan penilaian ECOG performance scale didapatkan skala 1 . Tekanan darah $130 / 80 \mathrm{mmHg}$, nadi $100 \mathrm{kali} / \mathrm{menit}$, regular, isi cukup, pernapasan 20 kali per menit, dan suhu tubuh $38,5^{\circ} \mathrm{C}$.

Pada pemeriksaan kepala didapatkan tidak terdapat rambut, konjungtiva tidak anemis, sklera tidak ikterik, bibir tidak 
sianosis, faring tidak hiperemis, tonsil tidak membesar dan merah. Pada pemeriksaan leher didapatkan tekanan vena jugularis $5+2 \mathrm{cmH}_{2} \mathrm{O}$, trakea letak di tengah, tidak terdapat pembesaran kelenjar getah bening leher. Pemeriksaan dada tampak asimetris, terlihat lokasi pemasangan chemoport pada dada kanan tampak agak kemerahan dan bengkak, nyeri pada perabaan, terlihat gerakan dinding dada kiri sama dengan kanan, fremitus raba kiri sama dengan kanan, perkusi sonor pada kedua paru, batas paru hati pada ruang sela iga VI kanan dengan peranjakan $1 \mathrm{~cm}$, suara pernapasan vesikuler di kedua paru, tidak terdapat ronki basah kedua lapangan paru, tidak terdapat wheezing. Pemeriksaan fisik jantung didapatkan iktus kordis tidak tampak, palpasi iktus kordis tidak teraba, batas kiri di ruang antar iga $\mathrm{V}$ garis midklavikula kiri, batas kanan di ruang antar iga IV $1 \mathrm{~cm}$ ke arah lateral garis sternal kanan, denyut jantung 100 kali per menit, irama teratur, bunyi jantung I dan II normal, tidak terdengar bising.

Pemeriksaan abdomen pada inspeksi didapatkan simetris, pada auskultasi bising usus dalam batas normal, pada perkusi didapatkan timpani di seluruh abdomen, pada palpasi datar, lemas, massa tidak teraba, tidak ada pembesaran hati dan limpa, tidak terdapat pembesaran kelenjar getah bening di lipat paha. Pemeriksaan anggota gerak didapatkan kulit hangat, edema tungkai tidak ada, terdapat nyeri tulang, tidak ditemukan paresa, tidak ditemukan tophy, sensibilitas normal dan kekuatan otot normal. tidak teraba membesar, konsistensi kenyal, nyeri tidak ada.

Pada hasil pemeriksaan laboratorium tanggal 26 November 2017 didapatkan kadar hemoglobin $(\mathrm{Hb}) 12,6 \mathrm{~g} / \mathrm{dL}$; leukosit $1000 / \mathrm{mm} 3$; hematokrit $34,2 \%$; trombosit $269.000 / \mathrm{mm} 3$; eritrosit $3,88 \times 10^{6} / \mu \mathrm{L}$. Hasil pemeriksaan hitung jenis leukosit pasien ini mendapatkan neutrofil batang 10\%; neutrofil segmen $36 \%$; eosinofil $2 \%$; basofil $0 \%$; limfosit 20\%; monosit 5\%; ureum $9 \mathrm{mg} / \mathrm{dL}$; kreatinin 0,6 mg/dL; gula darah sewaktu (GDS) $121 \mathrm{mg} / \mathrm{dL}$; natrium $133 \mathrm{mmol} / \mathrm{L}$; kalium 3,7 $\mathrm{mmol} / \mathrm{L}$; klorida $97 \mathrm{mmol} / \mathrm{L}$;
SGOT $15 \mathrm{U} / \mathrm{L}$; SGPT $14 \mathrm{U} / \mathrm{L}$; protein total $6.09 \mathrm{~g} / \mathrm{dL}$; fosfor $3.5 \mathrm{mg} / \mathrm{dL}$; magnesium $1.73 \mathrm{mg} / \mathrm{dL}$; albumin $3,54 \mathrm{~g} / \mathrm{dL}$; globulin $2.55 \mathrm{mg} / \mathrm{dL}$; kalsium 8,4 mg/dL. Pemeriksaan foto toraks didapatkan dalam batas normal. Pemeriksaan EKG didapatkan irama teratur, dengan laju jantung 100 kali/ menit, dengan kesan sinus takikardi.

Berdasarkan hasil anamnesis, pemeriksaan fisik, laboratorium dan pemeriksaan penunjang maka dibuat diagnosis kerja febrile neutropenia, infeksi lokal chemoport, kanker payudara kanan pasca kemoterapi. Pasien diberikan terapi infus $\mathrm{NaCl}$ 0,9\% 20 tetes/menit, ceftazidime injeksi 2 gr setiap 8 jam, filgastrim injeksi $300 \mathrm{mcg}$ setiap 24 jam subkutan. Pasien direncanakan untuk pemeriksaan kultur darah dan sensitivitas tes sserta kultur pada swab daerah chemoport. Pasien dikonsulkan ke bedah toraks kardiovaskuler untuk infeksi pada chemoport, kemudian ditindaklanjuti dari bedah toraks kardiovaskular untuk dilakukan hechting af, pemberian antibiotik, dan analgetik dilanjutkan.

Pada pemeriksaan fisik hari kedua masih didapatkan keluhan nyeri pada daerah chemoport. Keadaaan umum tampak sakit sedang, kesadaran kompos mentis, tekanan darah 100/70 mmHg, nadi 96x/ menit, reguler, isi cukup, respirasi $20 \mathrm{x} /$ menit, suhu tubuh $38,3^{\circ} \mathrm{C}$. Pada pemeriksaan daerah pemasangan chemoport masih terlihat bengkak dan nyeri pada perabaan. Tangan kanan terlihat bengkak. Pada hasil pemeriksaan laboratorium tanggal 28 November 2017 didapatkan hemoglobin (Hb) $11,2 \mathrm{~g} / \mathrm{dL}$; leukosit 3600/mm3; hematokrit $30.6 \%$; trombosit $233.000 / \mathrm{mm} 3$;

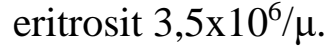

Pada pemeriksaan fisik hari keempat didapatkan nyeri pada daerah chemoport berkurang. Keadaaan umum tampak sakit sedang, kesadaran kompos mentis, tekanan darah 90/70 mmHg, nadi $100 \mathrm{x} / \mathrm{menit}$, reguler, isi cukup, respirasi $20 \mathrm{x} / \mathrm{menit}$, suhu tubuh $38^{\circ} \mathrm{C}$. Pemeriksaan di daerah sekitar pemasangan chemoport bengkak berkurang dan sudah tidak terlihat kemerahan.

Pada pemeriksaan fisik hari keenam didapatkan keluhan demam sudah tidak 
ada, nyeri daerah chemoport sudah berkurang. Keadaaan umum tampak sakit sedang, kesadaran kompos mentis, tekanan darah 110/70 mmHg, nadi $84 \mathrm{x} /$ menit, reguler, isi cukup, respirasi $20 \mathrm{x} /$ menit, suhu tubuh $36,5^{\circ} \mathrm{C}$. Pemeriksaan di daerah sekitar pemasangan chemoport sudah tidak bengkak. Hasil pemeriksaan laboratorium ialah hemoglobin $(\mathrm{Hb}) 11,2 \mathrm{~g} / \mathrm{dL}$; leukosit 4800/mm3; hematokrit $30,6 \%$; trombosit 236.000/mm3; eritrosit $3.5 \times 10^{\wedge} 6 / \mu$. Karena kondisi pasien membaik, maka pasien dipulangkan.

\section{BAHASAN}

Pada beberapa jenis kanker, demam dapat disebabkan oleh kanker itu sendiri. Kanker yang acap kali disertai demam disebabkan oleh metabolisme kanker itu sendiri (non infeksi) antara lain limfoma (69\%), leukemia (17\%), dan kanker payudara $(50 \%)$. Demam akibat infeksi pada pasien kanker umumnya toksik, menggigil, takikardi, kadang-kadang hipotensi sampai dengan syok. Demam kanker biasanya bersifat intermiten sebaliknya sementara infeksi biasanya tidak. ${ }^{2}$ Febrile neutropenia terjadi pada $10-50 \%$ pasien pasca kemoterapi dengan tumor padat dan lebih dari $80 \%$ pasca kemoterapi pada pasien dengan keganasan hematologik. ${ }^{7,8}$

Pada pasien ini ditemukan adanya demam, yaitu suhu aksila $\geq 38^{\circ} \mathrm{C}$ dan adanya neutropenia, dengan hasil ANC (absolute neutrophil count) $460 \mathrm{sel} / \mathrm{mm}^{3}$. Pasien mendapatkan kemoterapi kurang lebih 11 hari sebelum timbul gejala panas pertama kali dirasakan.

Stratifikasi risiko terjadinya demam neutropenia meliputi faktor-faktor seperti usia tertentu, jenis keganasan, dan faktor pengobatan seperti jenis kemoterapi. Penelitian oleh Lyman et $\mathrm{al}^{9}$ juga menyatakan jenis kelamin turut terlibat dalam terjadinya demam neutropenia. Pembagian faktor risiko dari Bakornas Hompedin (Badan Koordinasi Nasional hematologi Onkologi Medik penyakit Dalam Indonesia) tahun 2006 didasarkan pada jenis tumor (tumor padat atau hematologik), tipe kemoterapi (kemoterapi konvensional/intensif/agresif), adanya komorbiditas dan lamanya kondisi neutropenia. ${ }^{1}$ Disebut risiko rendah bila pasien menjalani kemoterapi konvensional, tidak ada komobiditas, netropenia berlangsung singkat $\leq 3$ hari, tidak didapatkan infeksi klinis serta tanda-tanda sepsis atau syok. Risiko sedang pada pasien dengan tumor solid atau keganasan hematologik, menjalani kemoterapi intensif, ada tidaknya komorbiditas, netropenia berlangsung 3-7 hari, didapatkan atau tidak didapatkan infeksi klinis, dan ada tidaknya tanda-tanda infeksi atau syok. Risiko tinggi pada pasien dengan keganasan hematologik, menjalani kemoterapi agresif/ PBSCT/ BMT, ada tidaknya komorbiditas, neutronpenia berlangsung $>7$ hari, didapatkan atau tidak didapatkan infeksi klinis, dan ada tidaknya tanda-tanda infeksi atau syok. ${ }^{1}$

Evaluasi besarnya risiko terjadinya komplikasi dari neutropenia dapat dilakukan dengan menggunakan skor risiko The Multinational Association for Supportive Care in Cancer (MASCC). ${ }^{9}$ Pada pasien ini didapatkan skor MASCC 20. Skor $\leq 21$ menunjukkan high risk komplikasi serius febrile neutropenia pada pasien kanker.

Neutropenia pada kanker tidak sama pada keadaan lain seperti demam tifoid, malnutrisi, dan anemia aplastik. Pada kanker terjadi produksi sitokin berlebihan yang menekan respon imun tubuh. Gangguan respon imun telah terjadi sejak amat dini pada pasien kanker. Gangguan respon imun pada pasien-pasien ini dapat terjadi pada berbagai lapisan imun yang non spesifik (limfosit T dan limfosit B). Gangguan limfosit $\mathrm{T}$ dapat diakibatkan infeksi bakteri, virus, jamur, atau protozoa. ${ }^{2}$

Pada demam neutropenia, organisme yang paling banyak menyebabkan demam infeksi dan bakteremia ialah bakteri Gram negatif, bakteri aerobik, dan kokus Gram positif. Bakteri Gram negatif (contoh Escherichia coli, Klebsiella, dan Pseudomonas aeruginosa) mendominasi neutropenia pada pasien kanker di tahun 1970 dan awal tahun 1980. Bakteri Gram positif (Staphylococcus dan Streptococcus viridans) mulai mendominasi akhir tahun 1980 dan awal 1990. Berdasarkan study case 
control oleh Pagano et $\mathrm{al}^{7}$ risiko terjadinya bakteremia pada pasien dengan keganasan hematologik ditemukan pada pemakaian kateter vena sentral dan neutropenia lebih dari 6 hari. Pemasangan kateter sentral sering berhubungan dengan infeksi Staphylococcus negative coagulase, $S$. aureus, dan kadang-kadang bakteri Gram negatif, yaitu Enterococcus dan Candida. Infeksi jamur dianggap sebagai infeksi sekunder namun juga bisa menjadi infeksi primer jika neutropenia bertahan selama lebih dari 10 hari. $^{6}$

Pengobatan antibiotik secara empiris sesegera mungkin diberikan tanpa menunggu konfirmasi infeksi melalui pemeriksaan laboratorium, karena infeksi dapat memburuk dengan sangat cepat pada pasien dengan febrile neutropenia. Pasien ini diterapi dengan antibiotik spektrum luas yaitu ceftazidime injeksi 2 gram setiap 8 jam. Tiga kelompok antibiotik yang dianjurkan secara empiris untuk pengobatan risiko tinggi, antara lain terapi kombinasi aminoglikosida dengan penisilin antipseudomonas atau dengan spektrum yang lebih luas seperti sefalosporin antipseudomonas atau dengan carbapenem, monoterapi dengan carbapenem, cefepime, ceftazidime atau piperacillin/tazobactam, kombinasi dari monoterapi atau ganda dengan vancomicyn untuk indikasi yang spesifik. ${ }^{6,7}$

Kemoterapi merupakan predisposisi infeksi pada pasien kanker dengan menekan produksi neutrofil akibat efek sitotoksis. Sitotastika sering menyebabkan hambatan proliferasi sel kulit dan mukosa, sehingga memudahkan invasi mikroorganisme karena erosi dan ulserasi serta menekan proliferasi sumsum tulang, termasuk granulosit yang berperan dalam imunitas non spesifik. Obat kemoterapi menyebabkan kerusakan sumsum tulang oleh efek anti metabolik, yaitu menyebabkan pencegahan sintesis DNA dan RNA sampai menyebabkan kerusakan dan penekanan sumsum tulang, yang menyebabkan menurunnya produksi neutrofil akibat gangguan imunitas. ${ }^{3}$ Contoh obat kemoterapi yang sangat terkait dengan neutropenia ialah aktinomisin, asparaginase, busulfan, cisplatin, doksorubisin, daunorubisin, etoposide, fluororacil, ifosfamis, dan methotrexate. ${ }^{6}$

Pasien ini mendapatkan kemoterapi kombinasi paclitaxel dan doxorubicin. Regimen kemoterapi ini digunakan untuk rekuren atau kanker payudara dengan metastase. Doxorubicin dapat menyebabkan kerusakan jantung tapi ini tidak umum terjadi pada orang yang tanpa riwayat penyakit jantung dari kemoterapi. Efek samping sementara yang sering ialah penurunan nafsu makan, mual, dan muntah, lemah badan, nyeri mulut, dan kerontokan rambut. Kemoterapi dapat menyebabkan siklus menstruasi berhenti sementara atau permanen. Penurunan jumlah sel darah merupakan efek samping serius yang paling sering terjadi. Kemoterapi merusak produksi sel darah oleh sumsum tulang. ${ }^{2}$

Pasien ini diberikan terapi filgastrim injeksi dengan dosis 300 mcg setiap 24 jam subkutan. Filgastrim diberikan dengan dosis $5 \mathrm{mcg} / \mathrm{kgBB}$ secara bolus subkutan atau infus IV jangka pendek (30 menit) setiap 24 jam hingga 2 minggu. Filgastrim merupakan G-CSF yang memiliki efek imunomodulator pada sel imun. G-CSF meningkatkan antibodi tergantung sitotoksisitas seluler dan produksi sitokin pada neutrofil. Filgastrim juga menghambat seperti sitokin pro-inflamasi yang dihasilkan oleh monosit dan makrofag. G-CSF disetujui oleh United States Food and Drug Administration (FDA) untuk digunakan mengurangi kejadian infeksi pada pasien dengan keganasan non-mieloid yang mendapat obat anti kanker mielosupresif yang berhubungan dengan kejadian demam neutropenia, mengurangi waktu untuk pemulihan neutrofil dan durasi demam. ${ }^{6}$ Setelah pemberian filgastrim, dapat dilihat perbaikan hasil laboratorium yaitu jumlah leukosit meningkat menjadi $4800 / \mathrm{mm} 3$ pada tanggal 2 Desember 2017.

\section{SIMPULAN}

Telah dilaporkan sebuah kasus pasien perempuan berusia 47 tahun dengan febrile neutropenia, infeksi lokal chemoport, kanker payudara kanan on kemoterapi. 
Diagnosis ditegakkan berdasarkan anamnesis, gejala dan tanda klinis, dan pada pemeriksaan laboratorium didapatkan ANC (absolute neutrophil count) $460 \mathrm{sel} / \mathrm{mm}^{3}$. Pasien diberikan terapi infus $\mathrm{NaCl} 0,9 \% 20$ tetes/menit, ceftazidime injeksi 2 gram setiap 8 jam, filgastrim injeksi $300 \mathrm{mcg}$ setiap 24 jam subkutan. Prognosis pada pasien ini secara ad vitam ialah dubia ad malam, ad functionam ialah dubia ad bonam, ad sanationam ialah dubia.

\section{Konflik Kepentingan}

Penulis menyatakan tidak terdapat konflik kepentingan dalam studi ini.

\section{DAFTAR PUSTAKA}

1. Ranuhardy D, Sari RM. Netropenia febrile pada kanker. In: Setiati S, Alwi I, Sudoyo AW, Simadibrata MK, Setiyohadi B, Syam AF, editors. Buku Ajar Penyakit Dalam Jilid III (6th ed). Jakarta: InternaPublishing, 2014.

2. Reksodiputro AH. Pengobatan suportif pada pasien kanker. In: Setiati S, Alwi I, Sudoyo AW, Simadibrata MK, Setiyohadi B, Syam AF, editors. Buku Ajar Penyakit Dalam Jilid III (6th ed). Jakarta: InternaPublishing, 2014.

3. Budiana IN, Febiani M. Febrile neutropenia pada pasien pasca kemoterapi. Indonesian Journal of Cancer. 2017; 11:77-82.
4. Lehrnbecher T, Phillips R, Alexander S. Guideline for the management of fever and neutropenia children with cancer and/or undergoing hematopoetic stem cell transplantation. J Clin Oncol. 2012; 30:4427-38.

5. Aalto $\mathrm{H}$. Markers of systemic inflammation in diagnostic and in prediction of outcome of community-acquired infection [Dissertation]. Helsinki: University of Helsinki; 2007.

6. Freifeld AG, Bow AJ, Sepkowitz KA, Boeckh MJ, Ito JI, Mullen CA, et al. Clinical practice guideline for the use of antimicrobial agents in neutropenic patients with cancer. CID. 2011;52:5793.

7. Pagano L, Taacconelli E, Tumbarello M, Laurenti L, Ortu-La Barbera E,Antinori $\mathrm{A}$, et al. Bacteriemia in patients with hematological malignancies. Analysis of risk factors, etiological agents and prognostic indicators. Haematologica. 1997;82:415-9.

8. Hassan BA, Yusoff Z, Otham S. Fever/clinical signs and association with neutropenia in solid cancer patients-bacterial infection as the main cause. Asian Pac J Cancer Prev. 2010;11:1273-7.

9. Lyman GH, Lyman CH, Agboola O. Risk models for predicting chemotherapyinduced neutropenia. Oncologist. 2005; 10:427-37. 